NBER WORKING PAPER SERIES

\title{
THE INTERGENERATIONAL EFFECTS OF WORKER DISPLACEMENT
}

\author{
Philip Oreopolous \\ Marianne Page \\ Ann Huff Stevens \\ Working Paper 11587 \\ http://www.nber.org/papers/w11587
NATIONAL BUREAU OF ECONOMIC RESEARCH
1050 Massachusetts Avenue
Cambridge, MA 02138
August 2005

This work was completed while Oreopoulos was a Statistics Canada Research Fellow and member of the Family and Labour Studies Division of Statistics Canada. The financial support of the National Science Foundation is gratefully acknowledged. We also wish to thank Miles Corak, and seminar participants at Brown University, MIT, Princeton University, Stanford University, Yale University, the University of California Berkeley, UCLA, the University of Toronto and the NBER summer institute for their helpful comments. The views expressed herein are those of the author(s) and do not necessarily reflect the views of the National Bureau of Economic Research.

(C2005 by Philip Oreopolous, Marianne Page and Ann Huff Stevens. All rights reserved. Short sections of text, not to exceed two paragraphs, may be quoted without explicit permission provided that full credit, including () notice, is given to the source. 
The Intergenerational Effect of Worker Displacement

Philip Oreopolous, Marianne Page and Ann Huff Stevens

NBER Working Paper No. 11587

August 2005

JEL No. J0

\section{$\underline{\text { ABSTRACT }}$}

This paper uses variation induced by firm closures to explore the intergenerational effects of worker displacement. Using a Canadian panel of administrative data that follows almost 60,000 father-child pairs from 1978 to 1999 and includes detailed information about the firms at which the father worked, we construct narrow treatment and control groups whose fathers had the same level of permanent income prior to 1982 when some of the fathers were displaced. We demonstrate that job loss leads to large permanent reductions in family income. Comparing outcomes among individuals whose fathers experienced an employment shock to outcomes among individuals whose fathers did not, we find that children whose fathers were displaced have annual earnings about $9 \%$ lower than similar children whose fathers did not experience an employment shock. They are also more likely to receive unemployment insurance and social assistance. The estimates are driven by the experiences of children whose family income was at the bottom of the income distribution, and are robust to a number of specification checks.

Philip Oreopoulos

University of Toronto

150 Saint George Street

Toronto, ON M5S 3G7

CANADA

and NBER

oreo@economics.utoronto.ca

Marianne Page

Department of Economics

1 Shields Avenue

University of California, Davis

Davis, CA 95616

and NBER

mepage@ucdavis.edu
Ann Huff Stevens

Department of Economics

1 Shields Avenue

University of California, Davis

Davis, CA 95616

and NBER

annstevens@ucdavis.edu 
It is well known that children from affluent families tend to have higher incomes as adults than children who grow up in poor families (Solon, 1992; Zimmerman, 1992). This pattern has convinced many social scientists and policymakers that family income plays an important role in determining children's life chances. Duncan and Brooks-Gunn (1997), for example, suggest that raising the incomes of poor families “...will enhance the cognitive development of children and may improve their chances of success in the labor market during adulthood.” Policy discussions often invoke the legacy of growing up in a poor family as evidence of the potential effectiveness of income transfer programs such as Aid to Families with Dependent Children. Despite such claims, the process that generates the intergenerational income correlation is not well understood. One possibility is that differences in income lead to differences in parents' monetary investments in their children. It is just as likely, however, that differences in income reflect differences in innate parental characteristics that parents pass onto their children.

Certainly, the magnitude of the intergenerational correlation is hard to ignore. Solon's (1999) survey of the intergenerational mobility literature suggests that the correlation between fathers' and sons' earnings is about 0.4. At issue is the extent to which this correlation reflects the importance of monetary vs. non-monetary family background characteristics. High income parents are likely to have other attributes such as high ability or motivation that independently have a positive affect on their children's outcomes. Cross-sectional comparisons of individuals who grew up in families with different income levels are thus likely to overstate the degree to which family resources matter.

This paper examines the effect of firm closings on the next generation's outcomes. ${ }^{1}$ Jacobsen, Lalonde and Sullivan (1993) (henceforth, JLS) and Stevens (1997) have documented that workers displaced by such events experience substantive long-lasting reductions in earnings, and they argue that firm closings can be thought of as exogenous employment shocks after conditioning on pre-displacement earnings. Our estimation strategy constructs narrow treatment

\footnotetext{
${ }^{1}$ When we include mass layoffs in our treatment group we obtain very similar results.
} 
and control groups of individuals whose fathers had the same levels of permanent income prior to 1982 when some of the fathers were displaced, and worked in firms of similar size and industry. Like previous studies, we demonstrate that displacement leads to permanent reductions in family income.

Comparing outcomes among individuals whose fathers experienced an employment shock to outcomes among individuals whose fathers did not, we find that children whose fathers were displaced have annual earnings that are about $9 \%$ lower than similar children whose fathers did not experience an employment shock. They are also more likely to receive unemployment insurance and social assistance. The estimates are driven by the experiences of children whose family income was at the bottom of the income distribution. The results suggest that the long term consequences of unexpected job loss extend beyond the effect on one's own income to the eventual labor market outcomes of one’s children.

\section{Background}

Understanding which factors contribute to the intergenerational transmission of income is crucial to the development of successful public policies. In the United States there are a number of programs designed to help low-income children, including Temporary Assistance to Needy Families, Medicaid, Head Start, Food Stamps, and public education. Some of these involve income transfers whereas others are direct-intervention programs. Mayer (1997) notes that throughout the history of the United States social policy has swung back and forth between the belief that material deprivation is the primary reason that poor children have poor outcomes, and the belief that parental characteristics that contribute to low incomes are mostly responsible for poor children's failure. Informed social policy depends critically on understanding which of these beliefs is correct. If, for example, money is a key determinant of children's outcomes then the effects of policies on family income should be a central consideration when evaluating their costs and benefits. On the other hand, if children's outcomes are mostly determined by innate 
parental characteristics that are correlated with income then social policy should be less concerned with income redistribution and focus more on addressing deficits in the other characteristics.

A number of cross-sectional studies show that positive income correlations remain even after controlling for a variety of parental characteristics (e.g. Corcoran et. al, 1992; Duncan and Hill, 1987), but these correlations are likely to overstate the degree to which parental income matters if some parental attributes that are positively correlated with income and children's outcomes cannot be observed. It is difficult to find compelling variation in income that is unrelated to parental characteristics that might affect child development (Duncan and BrooksGunn, 1997; Haveman and Wolfe, 1995). Shea (2000), for example, uses cross-sectional variation in fathers' earnings due to union status, industry wage differentials and involuntary job loss to identify the effects of parental income, but other researchers (Dickens and Katz, 1987; Gibbons and Katz, 1992; Lee, 1978) have argued that wage differences associated with these job characteristics reflect workers' innate attributes. Dahl and Lochner (2004) also create an instrument for income that includes family background characteristics (as well as changes in income induced by the Earned Income Tax Credit). ${ }^{2}$ Mayer (1997) controls for unobserved parental characteristics by adding to her regression a measure of parental income taken after the child's outcome is observed. She argues that future income is exogenous with respect to a previously measured outcome, so that it can serve as a proxy for the unmeasured components of family background. The success of this strategy requires that parental investment when the child is still at home is not influenced by the anticipation of future income, however. Blau (1999), Duncan, et. al. (1998) and Levy and Duncan (1999) all compare outcomes across siblings with different age-specific family income levels, but this approach can only identify the effect of

\footnotetext{
${ }^{2}$ The extent to which Dahl and Lochner's identification is driven by the EITC vs. these other family background characteristics is unclear to us.
} 
transitory changes in family income and it has been well documented that permanent income has a much stronger relationship with children’s long-term outcomes (Solon, 1999). ${ }^{3}$

Most existing studies that explore the effects of family resources on offspring's outcomes have been based on longitudinal datasets such as the Panel Study of Income Dynamics and the National Longitudinal Study of Youth, which are relatively small. It has turned out to be difficult to precisely identify parental income effects with so little data. The confidence interval around Shea's IV estimate of the effect of father's earnings on children's earnings, for example, includes effects ranging from approximately $-30 \%$ to $30 \%$. Solon’s (1999) comparison of sibling and intergenerational earnings correlations suggests that no more than $40 \%$ of the similarity in brothers' outcomes is likely due to factors related to their parents' income. While this leaves open the possibility that family income plays an important role in children's development it also suggests that when the data are limited to only a few thousand observations the effect may not be strong enough to estimate precisely.

This paper makes several contributions to the growing literature on intergenerational income mobility. First, by exploiting variation that is induced by firm closings, we can separate the effect of a long-lasting income shock from the effect of innate parental attributes. While cross-sectional differences in fathers' labor market characteristics are likely to reflect individual attributes, our longitudinal data allow us to construct narrow groups of "treatment" and "control” children whose families look identical before 1982, when some of the fathers lost their jobs. We base our analysis on a sample of children whose fathers worked continuously for the same firm between 1978 and 1981, and control for average family income, regional location, industry, and

\footnotetext{
${ }^{3}$ A very different approach is taken by Acemoglu and Pischke (2001) who use long-run trends in earnings levels at different points in the U.S. earnings distribution (and in different geographic regions) to generate exogenous income variation. They find that demographic groups with more sharply rising incomes also experienced larger increases in their children's educational attainment. One puzzle with these results is that, in their preferred specification, the return to education has no significant effect on college enrollment decisions. This may reflect the fact that their framework makes it difficult to control for both the current return to education and the change in parental income, since both are driven by the same national trends in returns to skill. The rise in return to skill should affect children's education directly, and so their strategy may not provide a valid instrument for changes in parental income.
} 
firm size during those four years. Thus, we are able to compare outcomes across children whose families would likely have had the same level of permanent income if the treatment fathers had not been displaced. A second advantage of our study is that it makes use of a longitudinal dataset that contains earnings and income observations on almost 60,000 father-son pairs. The sheer magnitude of this dataset substantially increases the precision with which intergenerational relationships can be estimated.

\section{Empirical Strategy}

We conduct our analysis in two stages. In the first stage, we use methods developed in the displacement literature to demonstrate that displacement has a substantive and long-lasting effect on a family's resources. The purpose of this part of the analysis is to make a convincing case that displacement produces an exogenous shock to family income. In the second stage, we use this information to identify the intergenerational effect of a family income shock.

\section{II.A. Estimating the Effect of Displacement on a Family's Resources}

We begin by following the empirical strategy introduced by JLS, and demonstrate that displacement has a large, persistent effect on a family's monetary resources. We start by regressing annual measures of family income, father's income and father's earnings on a full set of father's age fixed effects and a set of province by year dummy variables. ${ }^{4}$ The residual from this regression provides an annual estimate of family resources that is purged of life-cycle effects, province specific business-cycle effects and province-specific trends in earnings. We then regress this residual on a set of dummy variables indicating whether the father left his firm because the firm closed in a current, future or previous year. Specifically, given longitudinal data on fathers' labor market experiences, the effect of displacement on a family's resources is modeled in the following way:

\footnotetext{
${ }^{4}$ The province fixed effect is determined in the initial year the father is observed (1978).
} 
$\ln I_{i p t}=D_{i p t} \delta+\alpha_{i}+u_{i p t}$

where $\ln I_{\mathrm{ipt}}$ is the $\log$ of the residual of family $i$ 's resources in province $p$ and year $t$, and $D_{i p t}$ is a vector of dummy variables indicating that a displacement has taken (or will take) place in a future, current, or previous year. The error term has two components, a family-specific fixed effect, $\alpha_{i}$, and a random component, $u_{i p t}$. Since the model includes fixed effects, individual characteristics that do not vary over time, such as race and education, are not included.

The vector of displacement indicators $\left(D_{i p t}\right)$ contains three types of variables: dummy variables that equal one in the years prior to the displacement, a dummy variable equal to one in the year that the father loses his job, and a series of dummy variables indicating that a displacement took place in a previous year. The first set of indicator variables captures the possibility that the father's wages may begin to deteriorate prior to the actual displacement. This might happen if wages are cut when the firm hits difficult times: failure to include these dummies would lead to a biased estimate of the effect of the displacement. Our model, therefore, includes a dummy variable for each of the three years before the job loss occurs. The dummy variable indicating the year of the displacement captures its immediate effect on family resources, whereas the coefficients on the set of variables indicating that a displacement occurred in a previous year will reflect the persistence of the displacement effect over time. We follow the post-displacement period for eight years, including a dummy variable indicating that eight or more years have elapsed since the displacement took place. An eight year reduction in family resources comprises a significant fraction of the time a child is growing up, though most of the children in our sample will no longer be living at home at the end of the eight year period.

The error term in the above equation contains a time-invariant family-specific effect, $\alpha_{i}$, which measures average resources net of displacement. By including this fixed effect, we are able to separate variation in resources that is likely to be correlated with unobserved parental characteristics from variation due to a random shock. At the same time, the series of 
displacement dummies allows us to trace out the economic consequences in each year following the job loss and to estimate both the short-term and long-term effects, which may differ.

As will be discussed in Section III.B. the results from this exercise show that displacement substantively reduces family resources for many years. In order to facilitate our subsequent analyses, we will also estimate the effect of displacement using a version of equation (1) that replaces the individual fixed effect with the average of family income between 1978 and 1980 (which is at least two years before any displacements occur) and replaces the vector of displacement dummies with a single indictor for whether or not a displacement has occurred in the last five years or will occur in the next two years:

$\ln I_{i p t}=\operatorname{Shock}_{i p t} \delta+\phi$ AvgInc $_{78-80}+u_{i p t}$

where AvgInc is the family's (or father's) average income or earnings between 1978 and 1980, and Shock is a dummy variable equal to 1 if a displacement occurs during the displacement window described above. The coefficient on the Shock dummy indicates the average effect of displacement on family income over the years we study. The estimates produced by equations 12 will inform us about the magnitude and persistence of the economic losses that result from displacement.

\section{II.B. Estimating the Effect of Displacement on Children's Outcomes}

After documenting that job loss leads to a large, persistent decline in resources, we next use information about whether a child's father lost his job to identify the effect of an income shock on children's long-term economic outcomes. In this part of our analysis, we regress a measure of the child's economic well-being on average family income between 1978 and 1980 and the Shock dummy.

$O_{i}=a+$ bAvgInc $_{78-80}+$ CShock $_{i}+\varepsilon_{i}$ 
where $O_{i}$ represents an economic outcome for child $i$. Thus we compare outcomes across children whose parents experienced a job loss to outcomes for those whose parents did not, controlling for family income in the pre-displacement years. We also include a number of additional firm, region, and industry control variables that will be discussed in the next section. The key to this identification strategy is the assumption that after conditioning on fathers with similar income, in similar firms, industries, and regions, the families that experienced a displacement were ex ante no different from those who did not.

\section{Data}

Our analysis is based on data from the Intergenerational Income Database (IID), which is maintained by the Family and Labour Studies Division of Statistics Canada. The IID links tax information on children born between 1963 and 1970 to data on their parents, for all years between 1978 and 1999. The links were made possible using the T1 Family File (T1FF) of the Small Area and Administrative Data Division of Statistics Canada.

The T1FF is a data set of individual tax records that has been processed in a way that matches members of each tax filer's family. The primary way in which children are matched to their parents is through their name and address. In order to be identified as living in the same family, the child must file from the same address as the parent at least once during a five year period beginning when the child is 16-19 years of age. Evidence presented in Oreopolous (2003) suggests that this matching process picks up most adolescents in Canada. Younger children are more likely to be living at home, but less likely to file a tax return. ${ }^{5}$ All Canadians must file a tax return if they pay income tax in that year, and if they claim unemployment insurance benefits, a nonrefundable tuition tax credit or the monthly deduction for enrollment in a full-time education program. Since a child need only file once over a five year period in order to be included in the

\footnotetext{
${ }^{5}$ Note that a child may live away from home but still file from a parent's address, and thus be included in the IID. Children who are away at college fall into this category.
} 
sample, the vast majority of children make it into the IID. From the 1981 Canadian census, 96 percent of 17 year olds lived with a parent and 53 percent received non-transfer income in the previous year. Over 80 percent of 20 year olds lived with a parent, for and 73 percent of them received non-transfer income. Oreopoulos reports that the database includes 72 percent of youth who were 16-19 in 1982, 1984 or 1986 (the years in which the matches took place).

One way of exploring the representativeness of our sample is to compare the income distribution for children later in life to the income distribution for the same cohorts in the Census. Figure 1 plots 1995 income distributions for 25-33 year olds in the IID and the 1996 Census. It is clear that the IID misses a fraction of children who ultimately end up at the low end of the income distribution. In Section IV, we show that this is the group for whom our results are strongest, however, so it is likely that, if anything, this omission biases our estimates towards zero.

We have also examined whether there are differences in family size between those households with fathers who worked in firms that closed vs. those that did not. If there is selection into our treatment and control groups we might expect to see a correlation between family size (based on the number of children matching to the parents) and the corresponding father's displacement category. We do not find this. In 1982, the average number of children aged 12 to 19 per family is 1.81 among those whose fathers are classified as displaced, and 1.82 among those whose fathers are not.

The IID provides detailed administrative data on the incomes of children and their matched parents from 1978 to 1999. It also includes information on their age, gender, marital status, family composition, and residential address as well as an identification number for the firm at which the individual is employed. This ID number is used to match fathers in the IID to information about their firms from Statistics Canada's Longitudinal Employment Analysis Program database (LEAP). LEAP is a company-level database that includes all employers in Canada, both corporate and unincorporated. The database tracks the employment and payroll 
characteristics of individual firms from their year of entry to their year of exit. ${ }^{6}$ Employers in Canada are required to register a payroll deduction account and issue a T4 slip to each employee that summarizes earnings received in a given fiscal year. The LEAP database includes every business that issues a T4 taxation slip.

Only those already in the IID are matched to the LEAP firm identification number. Firm size is calculated as the number of fathers in the same firm in a given year. An internal match to the full LEAP database at Statistics Canada indicates the average ratio between total firm size and total father firm size for firms identified in the IID is 9.9. Thus, on average, the IID contains approximately a one-in-ten (non-random) sample of all employees in firms matched in both the IID and the LEAP database. Our sample also includes a 3 digit industry code for each firm and province location of firm's head office.

The longitudinal nature of the matched IID allows firm entry and exit to be identified on an annual basis. A firm closure is assigned in a given year if there are no IID fathers working at the firm in any following year (through 1999). ${ }^{7}$ In order to distinguish true closures from company reorganizations that lead to new identification codes, however, we do not count a firm as being closed if $35 \%$ or more of its workers move to the same "new" firm. ${ }^{8}$

Our main sample is limited to individuals who were between the ages of 12 and 14 in 1982. Information on older children is available in the IID, but we do not include these children because they are likely to have left home shortly after the displacement occurred. Information on

\footnotetext{
${ }^{6}$ Self-employed persons who do not draw a salary are not included on the LEAP database. In addition, businesses comprised solely of individuals or partnerships who do not draw a salary are also excluded from the LEAP.

${ }^{7}$ This may lead to some misclassifications. For example, if a firm disappears in 1983, we will identify the closing year as 1982. In some cases, the firm may have closed early enough in 1983 that it did not file T-4 slips.

${ }^{8}$ We examined the sensitivity of the results around this threshold using alternative values of 15 and 50 percent. Coefficient estimates for the main tables were similar. The standard errors were somewhat larger for the 15 percent threshold.

${ }^{9}$ We also explored displacement through mass layoffs. Identifying mass-layoffs is more difficult than firm closures because we can only observe what fraction of the firm leaves in between years, and this fraction depends on the firm's size. Firms can choose who leaves and for this reason we chose to focus on firm closures.
} 
younger children is not available. Children whose fathers are missing tax data are eliminated because without the tax data we cannot observe fathers' earnings, place of employment or labor market status. This restriction reduces the sample of fathers by about 11 percent. We also restrict the sample to children whose fathers were between the ages of 30 and 50 in 1978. This ensures that we are focusing on fathers whose incomes would have been relatively stable: earnings of young workers tend to be more volatile than those of workers who are over 30, and Stevens (1997) shows that the long-term effects of displacement are largest for workers with more years of tenure.

We also restrict our main sample to fathers who are initially working at firms that employed between 2 and 500 men (in the IID). We require that the firm employ at least 2 fathers because one-father firms will include self-employed fathers, and in order to reduce the possibility of mislabeling as displaced, men who voluntarily left small firms. An upper bound of 500 is chosen because closures at larger firms are extremely rare, and we were concerned that including such firms would introduce heterogeneity across the treatments and controls. Wage premiums are associated with large firms. Finally, we eliminate children whose fathers earned more than $\$ 1,000,000$ (measured in 1999 dollars) in a single year, in order to be sure that our estimates are not driven by outliers.

The treatment group consists of 12 to 14 year olds whose fathers experienced a displacement in 1982. Our primary control group consists of individuals whose fathers stayed with the firm through 1982, but who may have left after that. Fifty-six percent of fathers in this control group remained at the same firm until at least 1988. As part of our sensitivity analysis, we explore the consequences of including early leavers in our sample. We also show that the early exit rate (before 1982) is not correlated with closure in 1982, a finding similar to that of Hamermesh and Pfann (1996).

Our analysis focuses on the effects of displacements that occurred in 1982. Choosing this date allows us to base our sample on the children of fathers who had at least four years of tenure 
at the firm, while maximizing the number of years the children would be likely to be living at home after the displacement occurs. Another advantage of focusing on displacements that occurred in 1982 is that it was the beginning of a substantial and prolonged recession in Canada so that the number of displacement events is high.

The IID includes information on three socioeconomic outcomes: earnings, receipt of unemployment benefits, and receipt of social assistance. We use information that is available between 1995 and 1999 to create three dependent variables: the log of a five-year earnings average, an indicator for whether the individual received unemployment insurance during the five year period, and an indicator for whether the individual received social assistance during the five year period. Since earnings generally increase with age, we adjust our earnings measure by regressing it on a set of age dummies and use the residual as our dependent variable.

\section{Results}

\section{IV.A. Summary Statistics}

Sample summary statistics are shown in Table 1. Appendix Table A.1 includes additional information about the firms in our sample. As described above, most of our analysis focuses on children whose fathers were employed at firms with between 2 and 500 fathers. Our sample contains 54,145 fathers, 1,541 of whom experienced a firm closure in 1982. These men worked at 14,857 different firms, 509 of which closed during 1982. ${ }^{10}$ Control fathers remained with the same firm between 1978 and 1982.

Table 1 shows separate statistics for our treatment and control groups. Fathers' average age, income and earnings are initially very similar across the two groups, but by 1988, six years after treatment fathers have lost their jobs, the labor market characteristics of the two groups are

\footnotetext{
${ }^{10}$ The control group in the main sample may include fathers displaced after 1982. The fraction of displaced workers in the control, however, is likely to be small. We also considered an alternative control group that remained in the same firm between 1978 and 1988 and produced similar results with this group than with the control group we use here. The control group in our main sample is free to leave old and enter new firms, whether such a move occurs for positive or negative reasons.
} 
quite different. Average earnings of displaced fathers are roughly $\$ 43,000$, while the average earnings of the control fathers are roughly $\$ 49,000$. Not surprisingly, the displaced fathers are also much more likely to be receiving unemployment insurance. ${ }^{11} \quad$ Table 1 thus provides some initial evidence that firm closings generate substantial shocks to a family's economic status. At the same time, these shocks do not appear to affect other family background characteristics:

fathers' marital status and mothers' income, for example are very similar for the treatment and control groups in both 1978 and 1988.

Table 1 also shows that treatment and control children have somewhat different labor market outcomes. For example, average earnings between 1995 and 1998 are about \$21,000 among those whose fathers experienced a job loss and $\$ 23,000$ for those whose fathers did not. Similarly, treatment children have higher rates of UI and SA receipt than the controls.

The last column of Table 1 provides these descriptive statistics for all individuals in the IID who were 12-14 years old in 1982. Average family income is comparable, though slightly higher for these children. Otherwise, the samples are very similar.

\section{IV.B. The Monetary Costs of Displacement}

In this section we document that displacement leads to a substantive long-term reduction in family resources. We begin by graphing the average earnings trajectories of treatment and control fathers. Our earnings measure is the residual from a regression of earnings on age and province/year fixed effects, which allows us to abstract from life-cycle trends and provincespecific business cycles. Figure 2A makes clear that prior to 1982 the two groups experienced virtually identical earnings trajectories, lending weight to our hope that the treatment and control children come from similar backgrounds. At the same time we see that displacement produces a large and persistent shock to earnings. Both of these findings are necessary to our identification strategy. Figure 2B tells a similar story. Here we plot kernel density estimates of the earnings

\footnotetext{
${ }^{11}$ Information on social assistance receipt is not available prior to 1992.
} 
distributions for the two groups. The distributions are very similar prior to 1982, but after 1982 the distribution among displaced fathers is shifted substantially to the left.

We see a similar pattern when we look at receipt of UI (Figure 2C). ${ }^{12}$ As expected, displaced fathers experience a spike in benefit receipt in 1982, and by 1983, almost 40 percent of displaced father's are receiving UI benefits. UI use falls thereafter, but gradually, and never to the average levels of the non-displaced group. We also note that UI receipt rises in 1982 and 1983 among the control fathers. Some of these fathers may have been displaced from firms that did not meet our definition of a closure, or they may have claimed UI without being laid off.

Table 2 presents the results from our regressions of fathers' annual earnings and income on the displacement dummies. Columns 1 through 3 show estimates based on equation (1) using father's earnings, father's income, and parental income as the dependent variables. Like previous studies, we find that family resources decline substantially when a job loss occurs. For example, in the year following a job loss, father's earnings fall by $30 \%$, father's income falls by $19 \%$, and parental income falls by 13\%. ${ }^{13}$ Family resources recover somewhat over time, but even 8 years later earnings are approximately 15\% lower than they would have been if the displacement had not occurred. Similarly, the two income measures are reduced by 8 and 9 percent. These estimates are all statistically significant, and indicate that displacement produces substantive and persistent economic losses. They are similar to the estimates produced by JLS.

The first 3 rows of Table 2 also show what happens to family resources in the years prior to the displacement. As foreshadowed in Figure 1, there is no evidence that earnings or income begin to deteriorate prior to the job loss. The coefficient estimates are small and precisely estimated. This suggests that pre-displacement income can be included in our subsequent analysis as a control for permanent income.

\footnotetext{
${ }^{12}$ UI receipt is zero between 1978-1981, when the father was working at the same firm.

${ }^{13}$ The percentage effect on earnings is computed as $e^{\delta}-1$.

${ }^{14}$ A firm closure can occur anytime during the year. The fathers in our sample may, therefore, lose their job anytime between early January and late December. As a result, spells of unemployment and earnings losses may be larger in the year following the displacement than in the displacement year itself.
} 
The last three columns of Table 2 provide the estimates produced by estimation of equation (2). This paired-down version of equation (1) summarizes the monetary effect of displacement in a single coefficient, which is convenient for the second stage of the analysis. Similar to the first three columns of the table, the estimates suggest that men who lost their jobs in 1982 experienced permanent reductions in earnings and income of about $14 \%{ }^{15}$

\section{IV.C. Intergenerational Effects of Displacement}

Having established that displacement substantially reduces family resources, we now investigate whether it produces intergenerational effects. Table 3 displays the results from this second stage of our analysis. Dependent variables include the log of average earnings between 1995 and 1999, a dummy variable indicating whether the child filed for unemployment benefits between 1995 and 1999, and a dummy variable indicating whether she filed for social assistance between 1995 and 1999. Column 1 shows the results produced by an OLS regression of the log of child's earnings on the log of father's income between 1978 and 1980. Sample variation in this variable is likely to reflect variation in other family background characteristics though Figure 1 suggests that characteristics correlated with family income are unlikely to differ much between the treatment and control children. The estimated coefficient of 0.38 is consistent with the intergenerational correlations literature, which generally finds that the correlation between American fathers' and sons' earnings is about $0.40 .^{16}$

\footnotetext{
15 The estimates presented in Table 2 could be biased if displaced workers have unobserved characteristics that not only lower their earnings levels, but also their rate of earnings growth. In order to address this concern, we have also re-estimated equation (1) including father-specific time trends (equation 2). The results are very similar. Since the inclusion of person-specific trends does not appear to alter our estimates, we exclude these trends from the rest of our analyses.

${ }^{16}$ The correlation is significantly higher than that estimated for Canada by Corak and Heisz (1999). Some of the difference can be explained by our more selective sample of fathers in medium-sized firms for at least 5 years. Our correlation falls to 0.35 without this selection. Our correlation further reduces to 0.30 when keeping only sons and daughters aged 29 to 31 (which corresponds to Corak and Heisz' sample), and falls further to 0.28 when only looking at sons. Corak and Heisz find a correlation of about 0.25 .
} 
In the next column we include only a dummy variable indicating whether the father lost his job due to a plant closing. This variable has a powerful effect on the child's earnings, which are $8 \%$ lower than the earnings of those whose fathers were not displaced. Remarkably, this estimate barely changes even when we control for father's pre-1981 income (column 3). Furthermore, the point estimate on the log of pre-1981 income is robust to the inclusion of the displacement dummy. Taken together, these results suggest that our treatment and control groups are well-matched.

Column 4 adds firm-level controls to our model, including a quartic in father's firm size, the median wage, and 11 industry fixed effects. If the inclusion of these controls alters the estimated displacement coefficient then we should be concerned about the possible influence of family background characteristics. We also include 36 dummies indicating region of residence and urban/rural status, since firm closings that occur in company towns may have long lasting effects on local labor market conditions (Flint, Michigan comes to mind). If individuals tend to stay in the same location where they grew up then the displacement coefficient may partly reflect the fact that firm closings depress wages in the local economy. The estimated displacement coefficient is not changed by the addition of these controls, however. Furthermore, the estimates are robust to the inclusion of fixed effects that capture even more finely defined industry categories, such as at the three digit industry level.

The remainder of Table 3 shows what happens when we replace the dependent variable with indicators for whether the child received unemployment benefits or social assistance. These specifications also suggest that children whose parents experienced a job loss have worse economic outcomes than those whose parents did not. We find that children whose fathers were displaced are two percentage points more likely to receive unemployment benefits (though this is not statistically significant), and 3 percentage points more likely to receive social assistance as adults than those whose fathers remained at the same firm through 1982. The mean level of social assistance receipt in the second generation is 0.10 , so this estimated effect is very large. 
We have also repeated the analysis separately for boys and girls. While the results are not shown, they are very similar to those for the full sample, though the point estimates for girls are much less precisely estimated. The noisiness of the girls' estimates is undoubtedly driven by the fact that many women in their 20's and 30's choose not to work, or to work fewer hours while they are raising children, and not because they have poor labor market options. Women with no earnings between 1995 and 1999 are not observed.

Table 4 shows the sensitivity of the base line results from including more detailed region and industry fixed effects at the time of displacement. These estimates explore whether the main results simply capture local or region-specific shocks that affect everyone in these categories, not just those displaced. The analysis focuses on displacement effects within detailed region-industry groups. Keeping observations where at least one displaced father is matched to another nondisplaced father within a region-industry category produced similar results.

The baseline estimates for the intergenerational effects of displacement on earnings, unemployment receipt, and social assistance receipt are shown again in columns 1,4 , and 7 respectively. These results include 1-digit initial industry and initial province by urban-rural status fixed effects. The second set of columns (2, 5, and 8) include 317 3-digit industry categories. The estimated displacement effect increases slightly from -.086 to -.103 (while the standard error increases slightly). If we further condition on 180 local regions by controlling for the first 2-alphanumeric digits of the father's postal code of initial residence, the point estimate stays about the same, at -.094 , although the effect is significant only at the 10 percent level. The coefficients from estimating the displacement effects separately by fathers in rural or urban (Census Metropolitan Areas) also leads to similar point estimates.

The fall in annual income for children appears too large to attribute solely to the decline in family income from displacement. Table 2 suggests that the average effect of father's displacement on his own log earnings is approximately .14. The corresponding reduction in the second generation's earnings is about .08. This would imply that a one dollar reduction in 
father's permanent earnings leads to a subsequent reduction in his son's earnings of 34 cents. This is a very large effect, although the standard error estimate is also large.

Job loss is likely to impact the family in other ways than on income. Displacement disrupts the routine of everyday family life and may increase feelings of stress and anxiety. Spouses may try to compensate for the loss in income by working more. Lower income levels or subsequent re-employment could also be associated with residential moves, which are thought to have a negative impact on children (McLanahan and Sandefur, 1994). We explore some of these possibilities in Table 5 by estimating the effects of displacement on father's marital status and unemployment, mother's earnings, and residential mobility. We can also examine whether the inclusion of these variables affects the estimated effect of displacement on children's outcomes.

Column 1 provides, at best, weak evidence that fathers who lost their jobs are more likely to be divorced than fathers who did not lose their jobs. Two years after a firm closure, treatment fathers are 1.5 percentage points more likely to have divorced than control fathers, but the gap soon disappears, as the divorce rate among the control group rises for other reasons. We find stronger evidence of effects of displacement on residential mobility. Compared to children whose fathers are able to keep their jobs, displaced children are about 4 percentage points more likely to have moved in the short run and about 2 percentage points more likely to move in the long run. Unemployment insurance use is clearly higher among fathers displaced in 1982, even 8 years later. There is no evidence of a change in mother's earnings following the father's displacement.

Table 6 shows that divorce and residential mobility do not seem to explain any part of the displacement effects we estimate. Here we report results of regressions of kid's outcomes on family income prior to the job loss, the displacement dummy, and indicators for whether the parents divorce or move. The displacement effects are very similar to those shown in Table 3, suggesting that they are not driven by either divorce or residential mobility in the aftermath of displacement. 
An alternative way of investigating the possibility that our displacement effects are generated by factors unrelated to income is to add the log of average earnings between 1982 and 1988 to our basic specification:

$$
O_{i}=\beta_{1}+\beta_{2} \text { AvgInc }_{78-80}+\beta_{3} \text { AvgInc }_{82-88}+\beta_{4} \text { Shock }_{i}+\varepsilon_{i} .
$$

The estimates of $\beta_{3}$ and $\beta_{4}$ allow us to separate the displacement effect into an income component and a part that is unrelated to income. The results of this exercise, which are displayed in Table 7, suggest that the displacement effect is driven almost entirely by changes in income. The inclusion of post-displacement income leads to a dramatic fall in the estimated displacement coefficient, which is no longer statistically different from zero. At the same time, the estimated effect of post-displacement income on child's earnings is substantive. One needs to be careful in interpreting this coefficient because differences in father's 1983-1988 income, controlling for displacement, may be driven by variation in unobserved characteristics. The estimates in Table 7, however, are not consistent with a large portion of the displacement effects being driven by non-monetary factors.

Next, we consider how the displacement effects vary across the income distribution. Since the financial constraints and associated stress that accompany a job loss are likely to be larger for low income families, we expect that the intergenerational displacement effects will be largest for individuals who grew up in less affluent families. ${ }^{17}$ An advantage of basing our analysis on such a large dataset is that we can investigate this issue directly. In Table 8 we present displacement estimates separately by the family's (initial) income quartile. The displacement effects appear to be concentrated among those families for whom father's earnings are in the lowest quartile. Among children in this group subsequent earnings are $17 \%$ lower than they would have been if the father had not been displaced, and the probability of social assistance

\footnotetext{
${ }^{17}$ For example, Coelli (2004) finds that low income teenagers whose parents experience a job loss are less likely to attend college, and virtually all of this affect is concentrated among parents with only a high school education or less
} 
and UI receipt are 4 and 6 percentage points higher. In contrast, there is no evidence that there is any intergenerational effect among families in the top two quartiles. This finding may provide some insight as to why previous studies have failed to find income effects on the next generation: small sample sizes make it difficult to estimate nonlinear effects, yet virtually all of the action appears to be at the bottom of the income distribution.

\section{IV.D. Robustness Checks}

In the remainder of the paper we discuss several exercises that are designed to examine the sensitivity of our results to model specification and variable definitions. First, we investigate whether job losses that occur after children have left home have the same intergenerational effects as those that occur when the children are younger. A father's displacement should have a smaller psychological and financial effect on individuals who are no longer living in the household, so estimates of the same magnitude may be a sign that the displacement coefficient is picking up the effects of unobserved family background characteristics.

We investigate this possibility by aging our sample of children to 1989 and estimating the intergenerational effects of parental displacements that occur in that year. By 1989 our sample of children is between the ages of 19 and 21 and should be less sensitive to a parental job loss. In Table 9 we see the results from this exercise. Labor market outcomes are measured for the same cohorts of children whom we followed in Table 3, but by 1989 these children were 19-21 years old. As in Table 3, children's earnings and benefit receipt are measured between 1995 and 1999. Unlike Table 3, however, we see no evidence that parental job loss affects the next generation's outcomes: the estimated coefficient on the displacement variable is 0.008 , which is dramatically lower than the estimated displacement effect at younger ages, and it is not statistically different from zero. Similarly, the estimated effect on children's social assistance receipt is not statistically significant. This finding is particularly noteworthy because father's earnings losses following a 1989 displacement are even larger than those following a job loss in 1982: fathers 
who were displaced in 1989 experience short term earnings declines that are nearly double those experienced by fathers who lost their jobs in 1982.

Finally, we consider the possibility that our results are driven by heterogeneity across workers who leave firms before they close and those who are displaced at the time the firm shuts down. Our sample includes the latter, but not the former. One concern is that those who leave a firm before it closes are more able to obtain alternative jobs than those who stay until the firm shuts down. In this case our estimates would reflect only the experiences of children whose fathers are least likely to recover from displacement. We explore this possibility in Tables 10 and 11, where we extend our sample to include children whose fathers left the firm after 1979. Table 10 compares demographic characteristics in 1978 for those fathers who left the firm before it shut down in 1982 to those who were displaced by the firm closure. There is no evidence that "early leavers” have higher incomes, are of different ages, or have different marriage propensities than those who remain in the firm until it closes. Table 11 shows the results of IV regressions in which we use an indicator for whether or not the firm closed in 1982 as an instrument for whether the father was displaced in 1982. As we would expect, this instrument has strong predictive power: the first stage coefficient estimate is highly significant, and indicates that working in a firm that closes in 1982 increases the probability of leaving the firm in 1982 by $80 \%$. Also as expected, the reduced form regressions (not shown) of the child's outcome on whether the firm his father worked at in 1978 closed in 1982 produces smaller coefficient estimates than the estimated effects of displacement, but the IV estimates are of similar magnitude to those in Table 3, and retain their statistical significance.

\section{Conclusions}

This paper provides new evidence on the transmission of economic status across generations. While the existence of large intergenerational income correlations has lead many researchers to conclude that family income is an important determinant of children's eventual 
economic success, the evidence in support of this hypothesis is surprisingly limited. Previous research has been hampered by small sample sizes and the difficult task of controlling for unobserved parental attributes. Because we exploit longitudinal variation that is induced by firm closings we are able to separate the effect of a long-lasting income shock from the effect of innate parental attributes. Our access to a dataset that contains nearly 60,000 father/child pairs aids our ability to identify this effect.

We find that the adult earnings of children whose fathers were displaced are $8 \%$ lower than earnings of similar individuals whose fathers did not experience an employment shock, even after we account for fathers' pre-displacement earnings, initial region of work, industry and firm size. Relative to children whose fathers did not lose their jobs, children of displaced workers are also more likely to receive unemployment insurance and social assistance. Our estimates are driven almost exclusively by the experiences of individuals whose family income during childhood was in the bottom quartile of the income distribution. The results suggest that the long term consequences of unexpected job loss extend beyond the effect on one's own income to the eventual labor market outcomes of one's children.

The interpretation of these results relies on the quality of the control group. Our analysis assumes that the labor market experiences of control fathers provide an appropriate counterfactual for what would have happened to the treatment fathers if the displacement had not occurred. Put differently, we assume that conditional on 1978-1981 earnings and the other firm characteristic and region control variables, the likelihood that a job loss occurs is the same for the treatment and control groups. The fact that pre-displacement labor market characteristics are virtually identical for the two groups is a promising sign that we have successfully controlled for innate family background characteristics, but if treatment and control families differ in ways that affect the second generation's economic outcomes without affecting the economic outcomes of the parents, then our displacement effects will not be identified. It is hard to imagine what such characteristics would be, however. 
Finally, it is important to note that our estimation strategy captures the full effect of displacement. We have demonstrated that job loss leads to large, long lasting reductions in a family's monetary resources, but it may also impose non-monetary costs (such as stress, or residential mobility) on the family that affect the children's long-run outcomes. If the nonmonetary costs of displacement are substantial, our results could overstate the effect of a pure income shock. Suggestive evidence points to income as the major avenue through which displacement affects families, however.

The intergenerational effects of displacement estimated here point to the possibility that, particularly among the lowest income families, lasting reductions in family income can have substantial negative effects on children. This has not been a common finding in previous investigations of the causal link between parental income and children's outcomes. The qualitative difference between our findings and those in the earlier literature are likely to be related to three factors: our use of a large sample that allows for precise estimation of effects; the fact that displacement produces quite large and persistent reductions in family resources; and our ability to look at differential effects of the income shock across the income distribution. 


\section{References}

Blau, David M.; "The Effect of Income on Child Development," Review of Economics and Statistics, Vol. 81, No. 2, May 1999, pp. 261-76.

Corak, Miles and Andrew Heisz. 1999. "The Intergenerational Earnings and Income Mobility of Canadian men: Evidence from Longitudinal Income Tax Data." Journal of Human Resources 34(3):504-533.

Corcoran, Mary, Roger Gordon, Deborah Laren and Gary Solon; “The Association Between Men’s Economic Status and Their Family and Community Origins,” The Journal of Human Resources, Vol. 27, 575-601.

Dahl, Gordon and Lance Lochner, “The Impact of Family Income on Child Achievement,” mimeo, 2004.

Dickens, William and Lawrence Katz,“Inter-Industry Wage Differences and Industry Characteristics,” in Lang, K. and Leonard. J.,eds. Unemployment and the Structure of Labor Markets, Oxford Press 1987.

Duncan, Greg J., and Jeanne Brooks-Gunn, Consequences of Growing up Poor, 1997, Russell Sage Foundation, New York.

Duncan, Greg J., W. Yeung, Jeanne Brooks-Gunn, and Jeffery Smith, "How Much Does Childhood Poverty Affect the Life Chances of Children?” American Sociological Review, Vol. 63, 406-423, June 1998. 
Eissa, Nada and Jeffrey B. Liebman, "Labor Supply Response to the Earned Income Tax Credit,” Quarterly Journal of Economics, 111[2], May 1996, 605-637.

Eissa, Nada and Hilary W. Hoynes, “Taxes and the Labor Market Participation of Married Couples: The Earned Income Tax Credit,” Journal of Public Economics, 88[9-10], August 2004, 1931-58.

Gibbons, Robert and Lawrence Katz, “Does Unmeasured Ability Explain Inter-Industry Wage Differentials,” The Review of Economic Studies, 59(3), 515-535.

Hamermesh, Daniel S. and G. Pfann. "Turnover and the Dynamics of Labour Demand," Economica, August 1996.

Haveman, Robert and Barbara Wolfe; “The Determinants of Children’s Attainments: A Review of Methods and Findings,” Journal of Economic Literature, 33(4): 1829-1878, December, 1995.

Hill, Martha and Greg Duncan; "Parental Family Income and the Socioeconomic Attainment of Children,” Social Science Research, Vol. 16, 37-73.

Jacobson, Louis S., Robert J. LaLonde, and Daniel G. Sullivan; "Earnings Losses of Displaced Workers,” The American Economic Review, Vol. 83, No. 4, September 1993, pp. 685-709. 
Lee, Lung-Fei; “Unionism and Wage Rates: A Simultaneous Equations Model with Qualitative and Limited Dependent Variables,” International Economic Review, 19(2), 415433.

Levy, D. and Greg Duncan; "Using Sibling Samples to Assess the Effect of Childhood Family Income on Completed Schooling,” mimeo, 1999.

Mayer, Susan E., What Money Can’t Buy: Family Income and Children’s Life Chances, 1997, Harvard University Press, Cambridge MA.

Oreopoulos, Philip, “The Long-Run Consequences of Living in a Poor Neighborhood,” Quarterly Journal of Economics, Vol. 118, No. 4, November 2003; pp. 1533-75.

Page, Marianne E. and Gary Solon, “Correlations between Brothers and Neighboring Boys in Their Adult Earnings: The Importance of Being Urban,” Journal of Labor Economics, 21[4], October 2003: 831-55.

Shea, John; “Does Parents’ Money Matter?” Journal of Public Economics, Vol. 77, No. 2, August 2000; pp. 155-84.

Solon, Gary; “Intergenerational Income Mobility in the United States,” American Economic Review, Vol. 82, 393-408.

Stevens, Ann Huff, “Persistent Effects of Job Displacement: The Importance of Multiple Job Losses,” Journal of Labor Economics, Vol. 15, No. 1, Part 1., January 1997, pp. 165-88. 
Zimmerman, David; "Regression Towards Mediocrity in Economic Stature,” $\underline{\text { American }}$ Economic Review, Vol. 82, 409-429. 
Figure 1

Comparison of IID sample to 1986 Census

Kernel densities for total income among 25-32 year olds in 1995

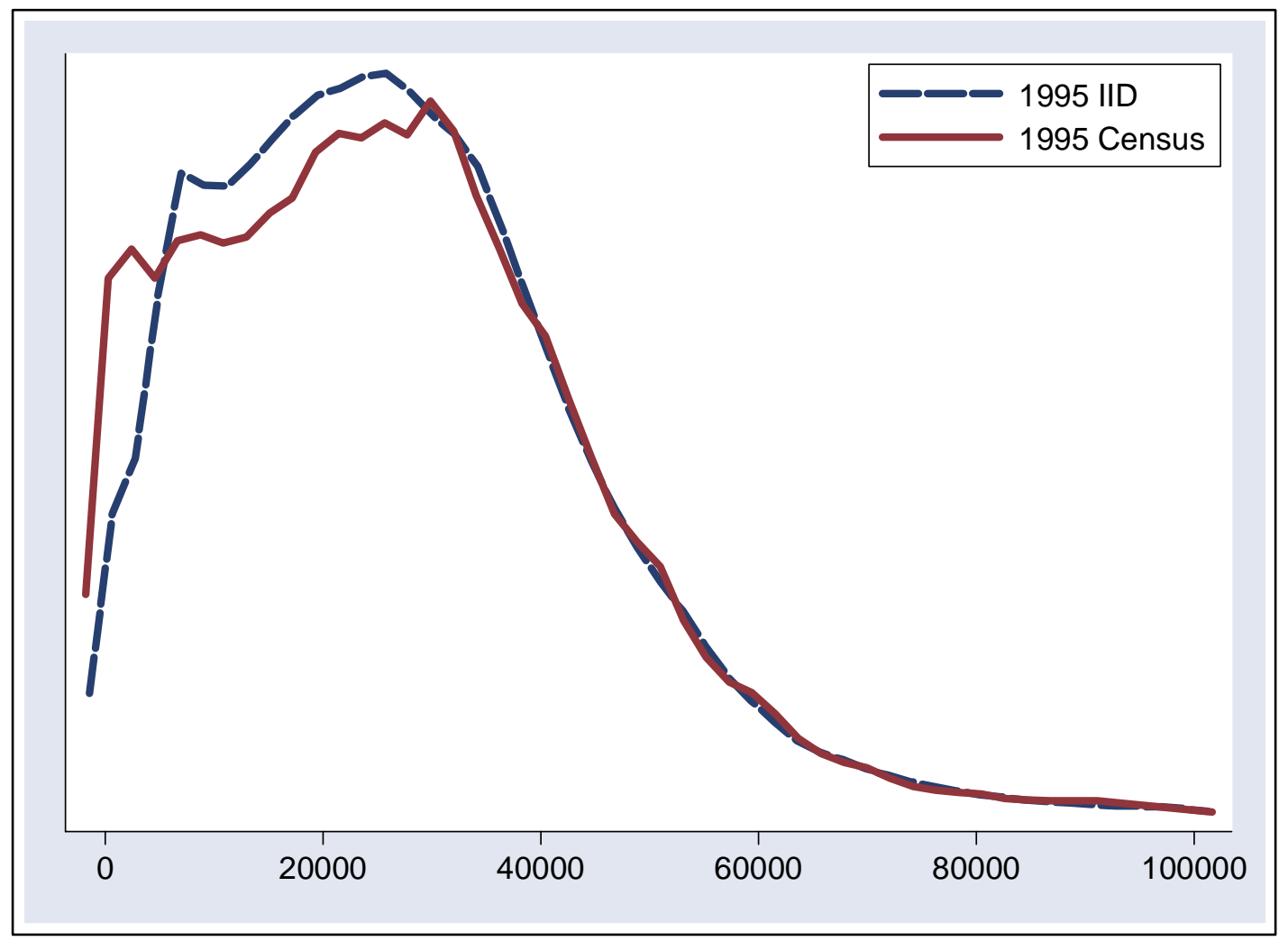


Figure 2A

Annual Average Father's Income

by Whether Firm Worked at between 1978 and 1982 Closed in 1982

Number of Father's at Initial Firm between 10 and 500

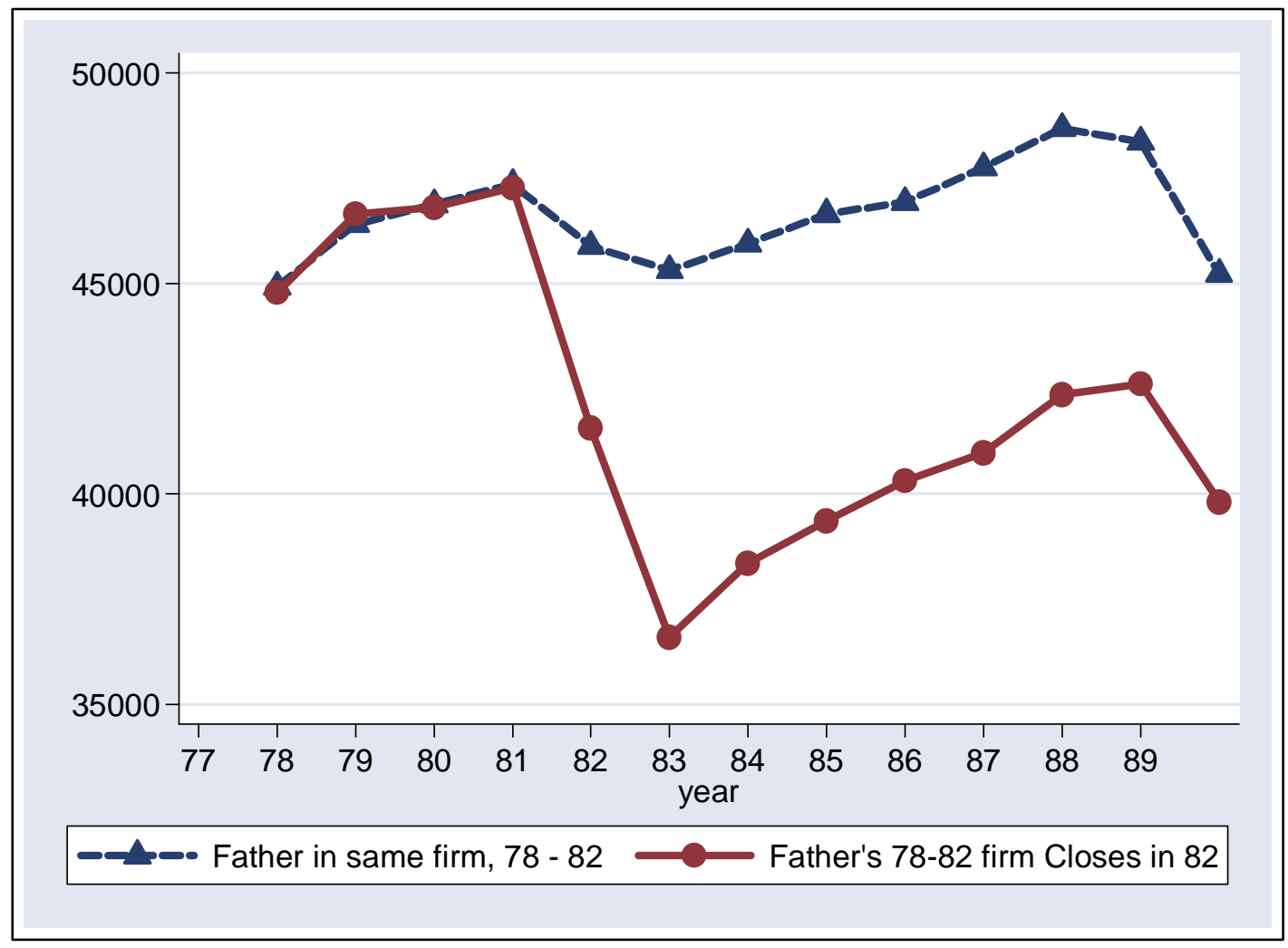


Figure 2B: Kernel Density of Father's Earnings by Displacement Status in 1982, 1978-89

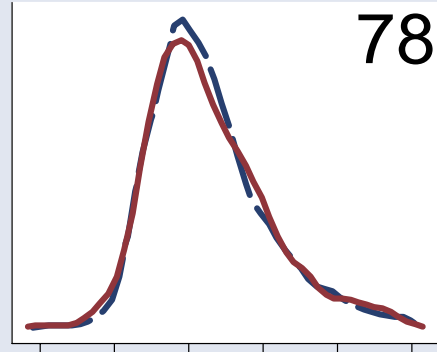

0 20000400006000080000100000 dminc
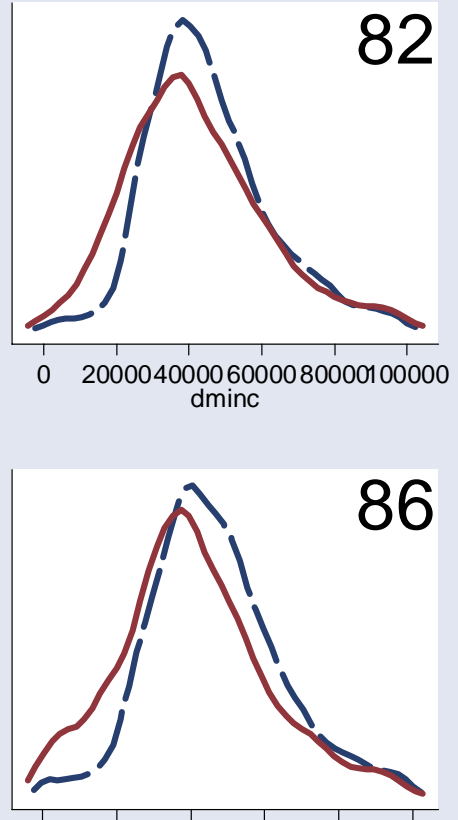

020000400006000080000100000 dminc

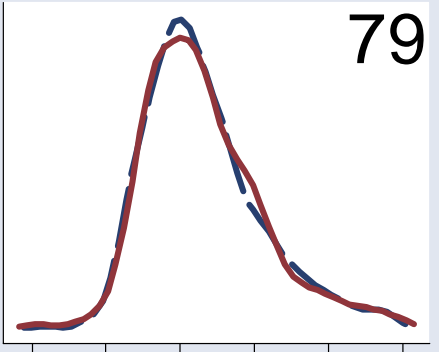

0 20000400006000080000100000 dminc

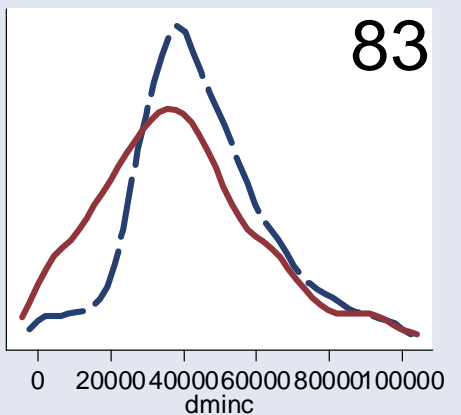

dminc

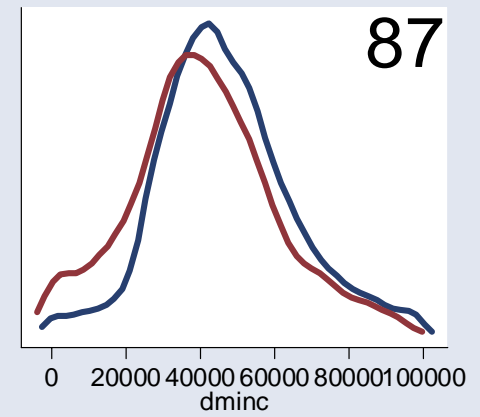

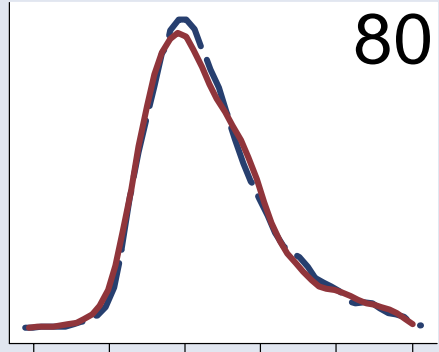

0220000400006000080000100000 dminc
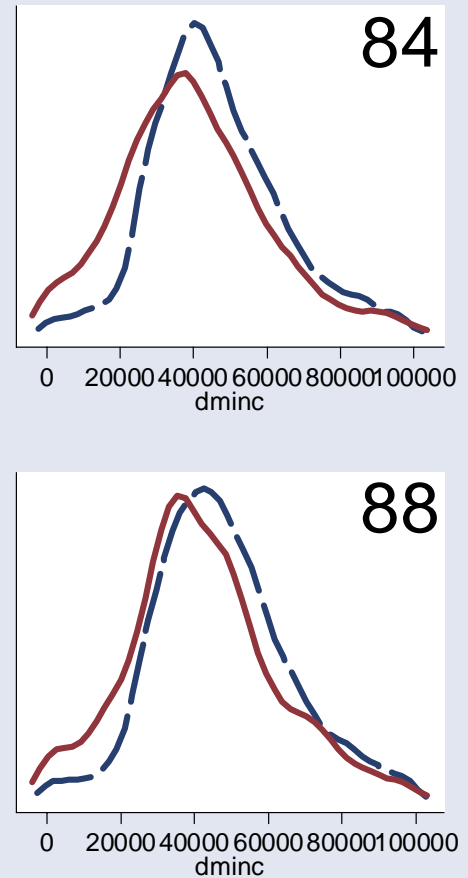

81

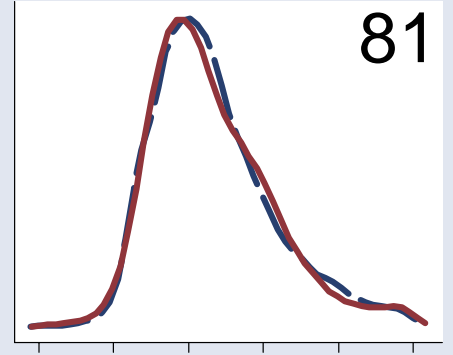

020000400006000080000100000 dminc
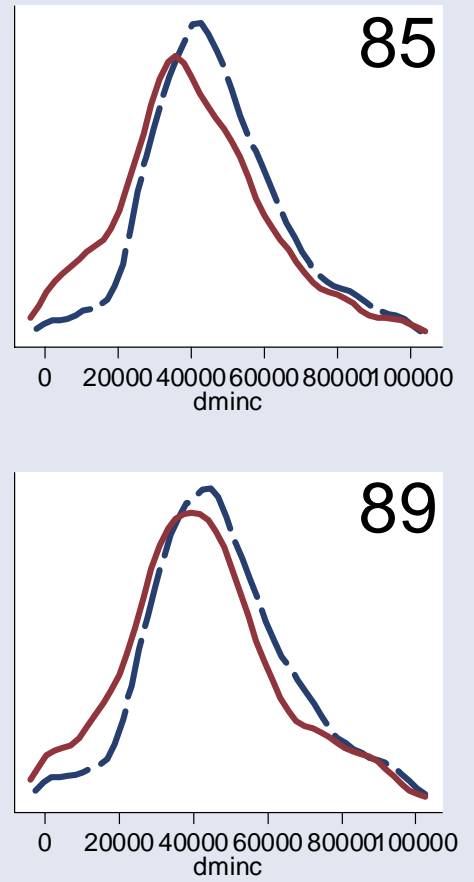
Figure 2C

Annual Average of Unemployment Insurance Receipt

by Whether Firm that Father Worked at between 1978 and 1982 Closed in 1982

Number of Father's at Initial Firm between 2 and 500

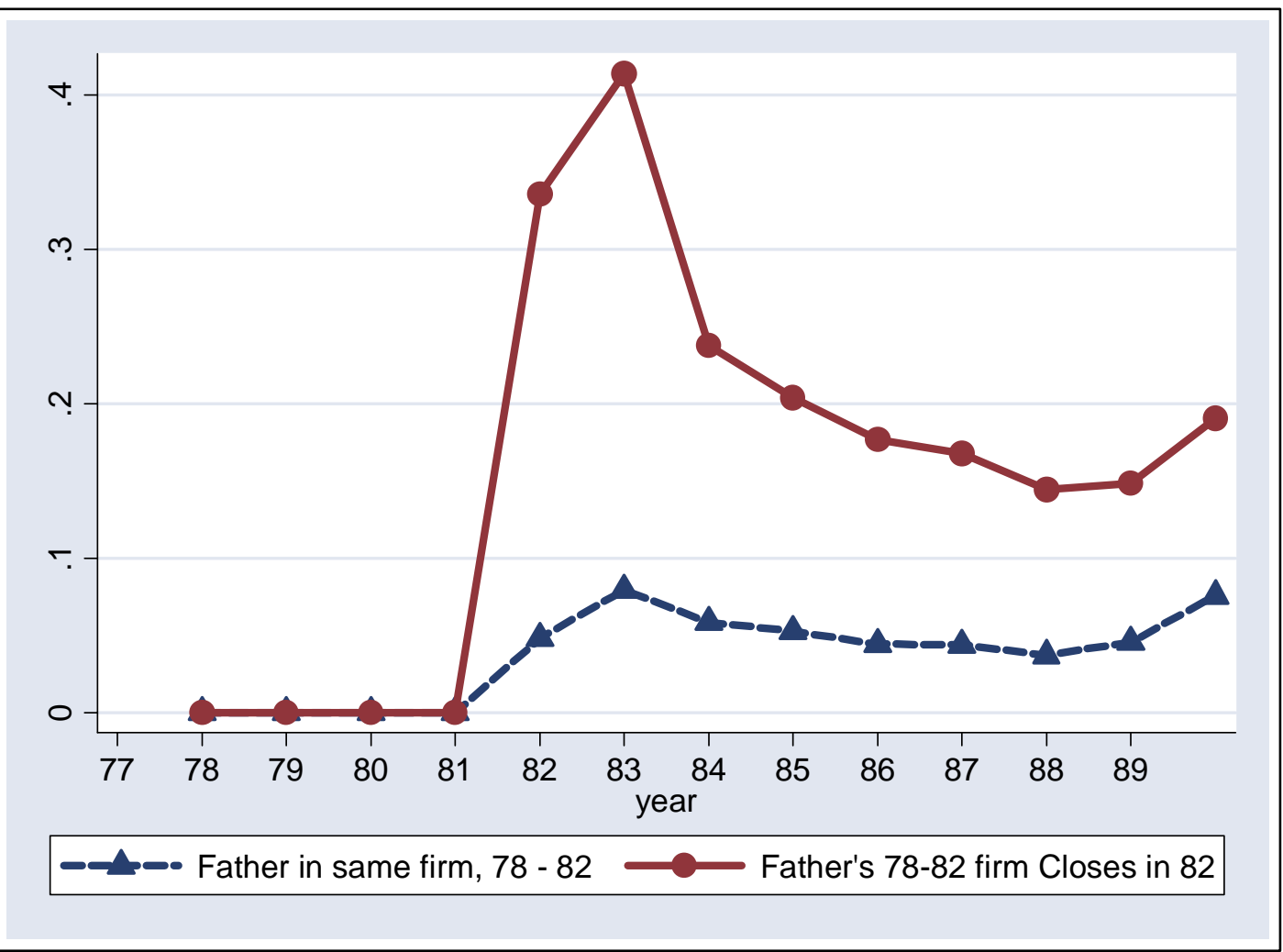


Table A.1

Descriptive Statistics, Firms

\begin{tabular}{|c|c|c|c|}
\hline & Closures & Controls & $\begin{array}{l}\text { All Children in IID } \\
\text { ages } 12 \text { to } 14\end{array}$ \\
\hline Average Father Firmsize & $\begin{array}{l}15 \\
(28)\end{array}$ & $\begin{array}{l}14 \\
(34)\end{array}$ & $\begin{array}{c}15 \\
(200)\end{array}$ \\
\hline Minimim Father Firmsize & 2 & 2 & 1 \\
\hline Maximim Father Firmsize & 493 & 496 & 27824 \\
\hline Average Median Wage & $\begin{array}{c}39,940 \\
(11,971)\end{array}$ & $\begin{array}{c}40,131 \\
(12,086)\end{array}$ & $\begin{array}{c}38,754 \\
(15,815)\end{array}$ \\
\hline \multicolumn{4}{|l|}{ Province } \\
\hline Newfoundland & 2.8 & 1.4 & 2.0 \\
\hline Prince Edward Island & 0.6 & 0.6 & 0.6 \\
\hline Noval Scotia & 2.6 & 3.0 & 3.6 \\
\hline New Brunswick & 3.4 & 2.4 & 2.8 \\
\hline Quebec & 31.2 & 32.0 & 30.9 \\
\hline Ontario & 37.8 & 42.6 & 38.2 \\
\hline Manitoba & 2.6 & 3.8 & 4.1 \\
\hline Saskatchewan & 2.6 & 2.9 & 4.0 \\
\hline Alberta & 12.5 & 7.3 & 8.9 \\
\hline British Columbia & 4.2 & 4.1 & 5.0 \\
\hline \multicolumn{4}{|l|}{ 1-Digit Industry } \\
\hline Missing & 0.2 & 0.0 & 0.1 \\
\hline Agriculture & 6.3 & 3.2 & 4.6 \\
\hline Primary Textiles and Leather & 2.2 & 5.6 & 3.4 \\
\hline Clothing and Furniture & 8.1 & 9.5 & 6.3 \\
\hline Manufacturing & 10.4 & 14.4 & 8.9 \\
\hline Construction and Transportation & 19.5 & 21.8 & 21.9 \\
\hline Wholesale Trade & 9.2 & 12.7 & 10.6 \\
\hline Retail Trade & 13.4 & 12.4 & 14.9 \\
\hline Finance and Insurance & 15.9 & 8.8 & 9.6 \\
\hline Education and Health Services & 5.1 & 4.4 & 9.1 \\
\hline Accomodation, Food and Bev. & 9.8 & 7.3 & 10.6 \\
\hline Number of Firms & 509 & 14,348 & 35,983 \\
\hline \multicolumn{4}{|c|}{$\begin{array}{l}\text { Note: Sample consists of all father-child pairs for which the child was between } \\
12 \text { and } 14 \text { in } 1982 \text { and the father worked at a firm with between } 2 \text { and } 500 \\
\text { fathers in the IID. Fathers must have worked at the same firm for four years } \\
\text { (between } 1978 \text { and 1981) and received no unemployment insurance during that } \\
\text { time. The 'closures' sample includes fathers displaced from a firm that closes in } \\
\text { 1982. Standard Deviations are in parenthesis. }\end{array}$} \\
\hline
\end{tabular}


Table 1

Descriptive Statistics, Fathers and Children

\begin{tabular}{|c|c|c|c|}
\hline & Closures & Controls & All Children in IID \\
\hline & \multicolumn{3}{|c|}{ Parents 1978} \\
\hline Father's Age & $\begin{array}{l}37 \\
(5)\end{array}$ & $\begin{array}{l}37 \\
(5)\end{array}$ & $\begin{array}{l}37 \\
(5)\end{array}$ \\
\hline Father's Earnings & $\begin{array}{c}43,066 \\
(16,905)\end{array}$ & $\begin{array}{c}43,136 \\
(15,829)\end{array}$ & $\begin{array}{c}44,986 \\
(16,839)\end{array}$ \\
\hline Father's Total Income & $\begin{array}{c}44,244 \\
(15,827)\end{array}$ & $\begin{array}{c}44,331 \\
(15,198)\end{array}$ & $\begin{array}{c}46,344 \\
(16,077)\end{array}$ \\
\hline Father on UI & 0.00 & 0.00 & 0.09 \\
\hline Father Married & $\begin{array}{c}0.95 \\
(0.22)\end{array}$ & $\begin{array}{c}0.96 \\
(0.21)\end{array}$ & $\begin{array}{c}0.95 \\
(0.21)\end{array}$ \\
\hline Mother's Earnings & $\begin{array}{c}7,971 \\
(11,297)\end{array}$ & $\begin{array}{c}7,756 \\
(11,479)\end{array}$ & $\begin{array}{c}8,067 \\
(12,238)\end{array}$ \\
\hline \multirow[t]{2}{*}{ Father Sample Size } & 1,541 & 52,604 & 165,325 \\
\hline & \multicolumn{3}{|c|}{ Parents 1988} \\
\hline Father's Age & $\begin{array}{l}47 \\
(5)\end{array}$ & $\begin{array}{l}47 \\
(5)\end{array}$ & $\begin{array}{l}47 \\
(5)\end{array}$ \\
\hline Father's Earnings & $\begin{array}{c}42,760 \\
(31,199)\end{array}$ & $\begin{array}{c}49,355 \\
(30,437)\end{array}$ & $\begin{array}{c}49,379 \\
(45,499)\end{array}$ \\
\hline Father's Total Income & $\begin{array}{c}44,098 \\
(30,189)\end{array}$ & $\begin{array}{c}50,228 \\
(58,664)\end{array}$ & $\begin{array}{c}50,454 \\
(43,669)\end{array}$ \\
\hline Father on UI & $\begin{array}{c}0.16 \\
(0.37)\end{array}$ & $\begin{array}{c}0.09 \\
(0.28)\end{array}$ & $\begin{array}{c}0.10 \\
(0.30)\end{array}$ \\
\hline married & $\begin{array}{c}0.88 \\
(0.33)\end{array}$ & $\begin{array}{c}0.87 \\
(0.33)\end{array}$ & $\begin{array}{c}0.87 \\
(0.34)\end{array}$ \\
\hline Mother's Total Income & $\begin{array}{c}14,987 \\
(15,683)\end{array}$ & $\begin{array}{c}15,000 \\
(17,374)\end{array}$ & $\begin{array}{c}15,795 \\
(18,090)\end{array}$ \\
\hline Moved from 1978 Address & $\begin{array}{c}0.53 \\
(0.50)\end{array}$ & $\begin{array}{c}0.49 \\
(0.50)\end{array}$ & $\begin{array}{c}0.49 \\
(0.50)\end{array}$ \\
\hline & \multicolumn{3}{|c|}{ Children 1995-1999 } \\
\hline Child's Earnings (95-99) & $\begin{array}{c}21,257 \\
(14,820)\end{array}$ & $\begin{array}{c}23,219 \\
(15,235)\end{array}$ & $\begin{array}{c}23,257 \\
(15,187)\end{array}$ \\
\hline Child's Age & $\begin{array}{l}29.9 \\
0.82\end{array}$ & $\begin{array}{l}30.0 \\
0.82\end{array}$ & $\begin{array}{l}29.9 \\
0.82\end{array}$ \\
\hline Child on UI at least once (95-99) & $\begin{array}{c}0.44 \\
(0.50)\end{array}$ & $\begin{array}{c}0.42 \\
(0.49)\end{array}$ & $\begin{array}{c}0.42 \\
(0.49)\end{array}$ \\
\hline Child on Welfare at least once (95-99) & $\begin{array}{c}0.13 \\
(0.33)\end{array}$ & $\begin{array}{c}0.10 \\
(0.30)\end{array}$ & $\begin{array}{c}0.10 \\
(0.30)\end{array}$ \\
\hline Number of Children & 1,718 & 57,963 & 176,930 \\
\hline
\end{tabular}

Note: Sample consists of all father-child pairs for which the child was between 12 and 14 in 1982 and the father worked at a firm with between 2 and 500 fathers in the IID. Fathers mus have worked at the same firm for four years (between 1978 and 1981) and received no unemployment insurance during that time. The 'closures' sample includes fathers displaced from a firm that closes in 1982. Standard Deviations are in parenthesis. 
Table 2

Effects of Displacement on Father's Real Log Earnings, Log Income and Mobility

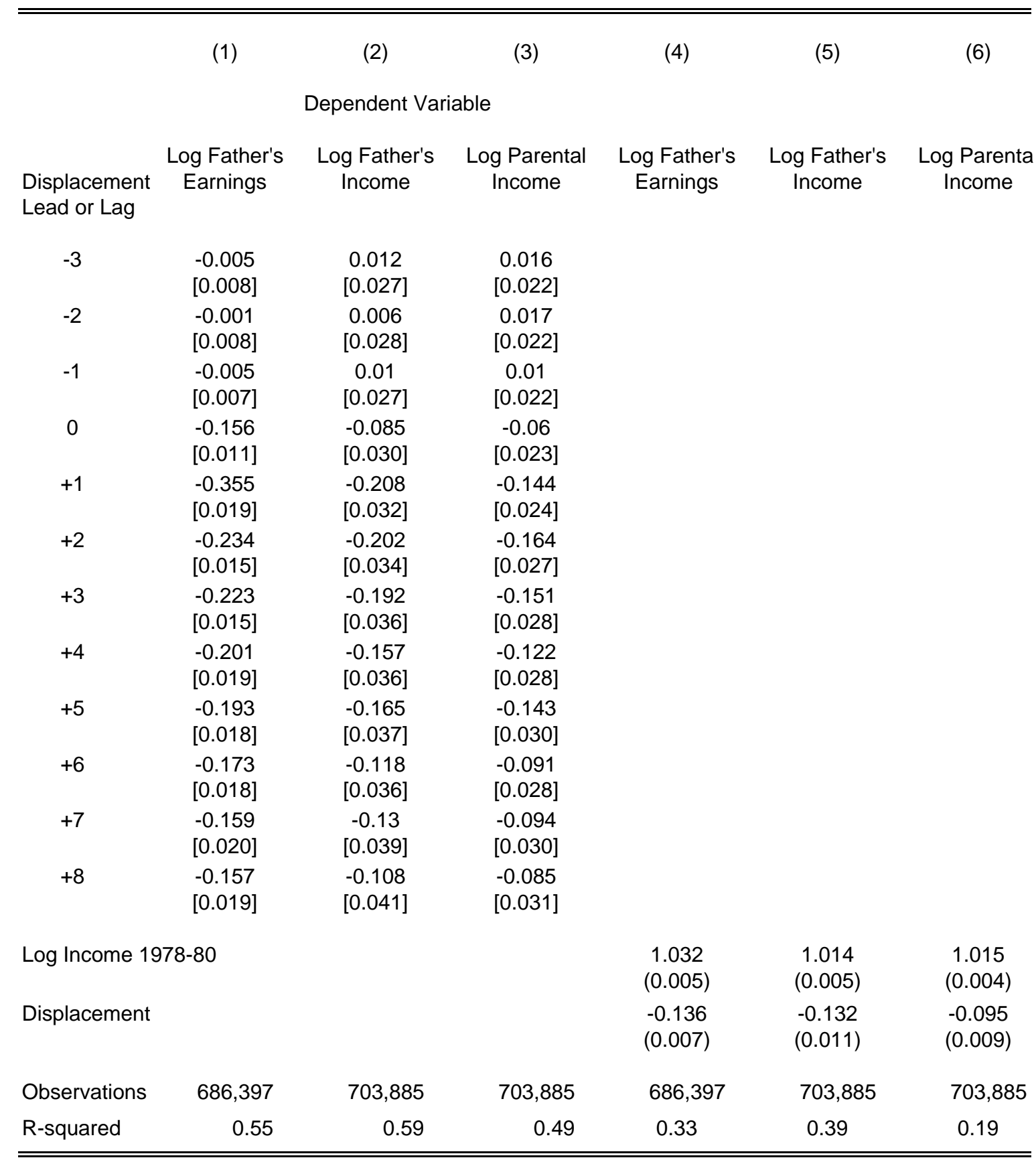

Note: Columns 1 through 3 show regressions using as dependent variables log father's annual earnings and log total income (both demeaned by age and year). The regressors are individual fixed effects and indicator variables for years since job displacement for fathers in firms that closed (the omitted category is not displaced or displacement in at least 3 years. Columns 4 through 6 show results from regressing the same dependent variables on average log earnings between 1978 and 1981, and a dummy variable for whether a father is displaced in 1982. 
Table 3

Estimated Effects of Father's Displacement

on Child's Earnings, Unemployment and Social Assistance Receipt

(1)

Age Adj. Lo
Earnings,
$1995-99$

0.383
$[0.023]$

Residual

[0.023]

Father Displaced

Characteristic Controls

Observations

R-squared
(2)

(4)

(5)

(6)

(7)

(8)

Social

$\begin{array}{lr}\text { Social } & \text { Social } \\ \text { Assistance }\end{array}$

Assistance Assistance

1995-99 1995-99

UI Receipt

UI Receipt

$-0.081$

$-0.047$

[0.004]

[0.023]

[0.024]

[0.007]

0.026

-0.086
$[0.040]$

$-0.086$

$-0.088$

0.016

0.018

[0.012]

0.025

[0.008]

[0.008]

Yes

No

Yes

No

Yes

No

59,681

59,681

59,681

0.05

0.02

0.05

0

0.02

Note: The dependent variable in columns 1-4 is child's log real earnings averaged between 1995 and 1999 after de-meaning by age. All regressions include fixed effects for birth cohort interacted with gender. The initial firm characteristic controls include fixed effects for regional location of firm (18 possible characters that identify provinces and smaller regions in large provinces) interacted with an indicator variable for whether the firm is in an urban or rural location. The controls also include 11 industry categories and the median log wage of the initial firm in 1978 . HuberWhite standard errors are shown from clustering by father ID. 
Table 4

Estimated Effects of Father's Displacement on Child's Outcomes

Conditional on Region and Industry Fixed Effects

(1)

(2)

(4)

(6)

(7)

(8)

Age Adj. Log Age Adj. Log Age Adj. Log

Earnings,

Dep var:

1995-99

1995-99

Earnings,

UI Receipt

UI Receipt

UI Receipt

Social

Assistance

Social

Assistance

Receipt

Social

$0.368 \quad 0.365$

Residual

0.383

[0.020]

[0.023]

$-0.047$

$-0.053$

$-0.103$

$-0.094$

[0.049]

[0.007]

[0.007]

$-0.054$

[0.008]

$-0.081$

-0.081
$[0.004]$

$-0.076$

[0.004]

$\left.\begin{array}{ll}-0.086 & -0.039]\end{array}\right]$

0.018

[0.012]

0.011

[0.014]

0.012

[0.017]

0.026

0.033

[0.009]

$-0.074$

[0.005]

0.028

With Initial Firm

Characteristic Controls

Yes Yes

Yes

Yes

Yes

Yes

Yes

Yes

[0.010]

Number of initial industry F.E. $\quad 10$

Number of initial region F.E. $\quad 36$

10

317

317

180

36

36

57,683

59,681

59,681

0.05

0.13

59,681

0.13

0.24

0.24

0.02

59,681

59,681

Notes: The dependent variable in columns 1-4 is child's log real earnings averaged between 1995 and 1999 after de-meaning by age. All regressions include fixed effects for birth cohort interacted with gender. The initial firm characteristic controls include fixed effects for regional location of firm interacted with an indicator variable for whether the firm is in an urban or rural location. The controls also include 11 industry categories and the median log wage of the initial firm in 1978. Huber-White standard errors are shown from clustering by father ID. 
Table 5

Estimated Effects of Father's Displacement

On the Probability of Divorce, Residential Moves, and Mother's Income

\begin{tabular}{|c|c|c|c|c|}
\hline & $\begin{array}{l}\text { Ever Not } \\
\text { Married } \\
\text { since } \\
1978\end{array}$ & endent Vari & $\begin{array}{l}\text { Mother's } \\
\text { Earnings }\end{array}$ & $\begin{array}{l}\text { Unemp. } \\
\text { Insurance } \\
\text { Receipt }\end{array}$ \\
\hline \multicolumn{5}{|l|}{$\begin{array}{l}\text { Displacement } \\
\text { Lead or Lag }\end{array}$} \\
\hline-3 & $\begin{array}{c}0 \\
{[0.003]}\end{array}$ & $\begin{array}{c}0.008 \\
{[0.008]}\end{array}$ & $\begin{array}{c}53.681 \\
{[98.772]}\end{array}$ & $\begin{array}{l}-0.011 \\
{[0.006]}\end{array}$ \\
\hline-2 & $\begin{array}{c}0.001 \\
{[0.004]}\end{array}$ & $\begin{array}{c}0.003 \\
{[0.009]}\end{array}$ & $\begin{array}{l}-200.147 \\
{[130.319]}\end{array}$ & $\begin{array}{l}-0.015 \\
{[0.006]}\end{array}$ \\
\hline-1 & $\begin{array}{c}0.001 \\
{[0.005]}\end{array}$ & $\begin{array}{c}0.006 \\
{[0.010]}\end{array}$ & $\begin{array}{l}-250.188 \\
{[160.781]}\end{array}$ & $\begin{array}{c}-0.01 \\
{[0.006]}\end{array}$ \\
\hline 0 & $\begin{array}{c}0.006 \\
{[0.005]}\end{array}$ & $\begin{array}{c}0.039 \\
{[0.010]}\end{array}$ & $\begin{array}{l}-265.791 \\
{[169.206]}\end{array}$ & $\begin{array}{c}0.233 \\
{[0.012]}\end{array}$ \\
\hline+1 & $\begin{array}{c}0.007 \\
{[0.006]}\end{array}$ & $\begin{array}{c}0.04 \\
{[0.010]}\end{array}$ & $\begin{array}{l}-179.216 \\
{[180.592]}\end{array}$ & $\begin{array}{c}0.281 \\
{[0.012]}\end{array}$ \\
\hline+2 & $\begin{array}{c}0.015 \\
{[0.007]}\end{array}$ & $\begin{array}{c}0.035 \\
{[0.011]}\end{array}$ & $\begin{array}{c}26.057 \\
{[190.868]}\end{array}$ & $\begin{array}{c}0.135 \\
{[0.010]}\end{array}$ \\
\hline+3 & $\begin{array}{c}0.01 \\
{[0.008]}\end{array}$ & $\begin{array}{c}0.035 \\
{[0.011]}\end{array}$ & $\begin{array}{c}-32.187 \\
{[218.225]}\end{array}$ & $\begin{array}{c}0.112 \\
{[0.010]}\end{array}$ \\
\hline+4 & $\begin{array}{c}0.007 \\
{[0.008]}\end{array}$ & $\begin{array}{c}0.034 \\
{[0.011]}\end{array}$ & $\begin{array}{l}-123.249 \\
{[222.071]}\end{array}$ & $\begin{array}{c}0.077 \\
{[0.009]}\end{array}$ \\
\hline+5 & $\begin{array}{c}0.007 \\
{[0.009]}\end{array}$ & $\begin{array}{c}0.028 \\
{[0.011]}\end{array}$ & $\begin{array}{c}32.499 \\
{[251.133]}\end{array}$ & $\begin{array}{c}0.065 \\
{[0.009]}\end{array}$ \\
\hline+6 & $\begin{array}{c}0.004 \\
{[0.009]}\end{array}$ & $\begin{array}{c}0.025 \\
{[0.011]}\end{array}$ & $\begin{array}{c}-67.235 \\
{[284.825]}\end{array}$ & $\begin{array}{c}0.06 \\
{[0.009]}\end{array}$ \\
\hline+7 & $\begin{array}{c}0.004 \\
{[0.009]}\end{array}$ & $\begin{array}{c}0.02 \\
{[0.011]}\end{array}$ & $\begin{array}{l}-191.588 \\
{[287.696]}\end{array}$ & $\begin{array}{c}0.046 \\
{[0.009]}\end{array}$ \\
\hline+8 & $\begin{array}{c}0.004 \\
{[0.009]}\end{array}$ & $\begin{array}{c}0.018 \\
{[0.011]}\end{array}$ & $\begin{array}{c}-19.425 \\
{[294.987]}\end{array}$ & $\begin{array}{c}0.055 \\
{[0.010]}\end{array}$ \\
\hline Observations & 703885 & 703885 & 703885 & 703885 \\
\hline R-squared & 0.6 & 0.69 & 0.76 & 0.28 \\
\hline
\end{tabular}

Notes: The regressors are individual fixed effects and indicator variables for years since job displacement for fathers in firms that closed (the omitted category is not displaced or no displacement for at least 3 years. 
Table 6

Estimated Effects of Father's Displacement, Divorce, and Mobility on Child's Earnings, Unemployment and Social Assistance Receipt

\begin{tabular}{lccc}
\hline \multicolumn{3}{c}{ Dependent Variable } & \\
& Age Adj. & & \\
& Log & & Social \\
& Earnings, & & Assistance \\
& $1995-99$ & Ul Receipt & Receipt \\
\hline \hline Log Income 1978-80 & 0.36 & -0.045 & -0.074 \\
& {$[0.026]^{\star \star \star}$} & {$[0.007]^{\star \star \star}$} & {$[0.005]^{\star \star \star}$} \\
Displacement & -0.088 & 0.017 & 0.025 \\
& {$[0.044]^{\star \star}$} & {$[0.013]$} & {$[0.009]^{\star \star \star}$} \\
Father Divorced & -0.204 & 0.017 & 0.078 \\
& {$[0.032]^{\star \star \star}$} & {$[0.010]^{\star}$} & {$[0.007]^{\star \star \star}$} \\
Moved & -0.027 & -0.009 & 0.016 \\
& {$[0.025]$} & {$[0.008]$} & {$[0.006]^{\star \star \star}$} \\
& & & \\
Observations & 703,885 & 703,885 & 703,885 \\
R-squared & 0.05 & 0.05 & 0.02 \\
\hline \hline
\end{tabular}

Note: The dependent variables are is child's log real earnings averaged between 1995 and 1999 after de-meaning by age, a dummy for ever receiving UI between 1995 and 1999, and a dummy for ever receiving Social Assistance between 1995 and 1999. All regressions include fixed effects for birth cohort interacted with gender. 
Table 7

Effects of Father's Income and Father Displacement

on Child's Earnings, Unemployment and Social Assistance Receipt

Controlling for Father' Income 1983-1988

\begin{tabular}{|c|c|c|c|c|c|c|}
\hline & (1) & (2) & (3) & (4) & (5) & (6) \\
\hline Dep var: & $\begin{array}{l}\text { Log } \\
\text { Earnings } \\
\text { Residual }\end{array}$ & $\begin{array}{l}\text { Log } \\
\text { Earnings } \\
\text { Residual }\end{array}$ & UI Receipt & UI Receipt & $\begin{array}{c}\text { Social } \\
\text { Assistance } \\
\text { Receipt }\end{array}$ & $\begin{array}{c}\text { Social } \\
\text { Assistance } \\
\text { Receipt }\end{array}$ \\
\hline $\begin{array}{l}\text { Father's Log Income } \\
\text { Residual, } 1978 \text { - } 1981\end{array}$ & $\begin{array}{c}0.376 \\
{[0.024]}\end{array}$ & $\begin{array}{c}0.158 \\
{[0.034]}\end{array}$ & $\begin{array}{l}-0.046 \\
{[0.007]}\end{array}$ & $\begin{array}{c}-0.02 \\
{[0.009]}\end{array}$ & $\begin{array}{c}-0.08 \\
{[0.004]}\end{array}$ & $\begin{array}{l}-0.038 \\
{[0.006]}\end{array}$ \\
\hline Father Displaced & $\begin{array}{l}-0.086 \\
{[0.039]}\end{array}$ & $\begin{array}{l}-0.027 \\
{[0.039]}\end{array}$ & $\begin{array}{c}0.018 \\
{[0.012]}\end{array}$ & $\begin{array}{c}0.004 \\
{[0.012]}\end{array}$ & $\begin{array}{c}0.026 \\
{[0.008]}\end{array}$ & $\begin{array}{c}0.009 \\
{[0.008]}\end{array}$ \\
\hline $\begin{array}{l}\text { Father's Log Income } \\
\text { Residual, } 1983 \text { - } 1988\end{array}$ & & $\begin{array}{c}0.224 \\
{[0.022]}\end{array}$ & & $\begin{array}{l}-0.027 \\
{[0.006]}\end{array}$ & & $\begin{array}{l}-0.043 \\
{[0.004]}\end{array}$ \\
\hline $\begin{array}{l}\text { With Initial Firm } \\
\text { Characteristic Controls }\end{array}$ & Yes & Yes & Yes & Yes & Yes & Yes \\
\hline Observations & 57683 & 57683 & 59681 & 59681 & 59681 & 59681 \\
\hline R-squared & 0.05 & 0.05 & 0.05 & 0.05 & 0.02 & 0.02 \\
\hline
\end{tabular}

Notes: The dependent variable in columns 1-2 is child's log real earnings averaged between 1995 and 1999 after de-meaning by age. All regressions include fixed effects for birth cohort interacted with gender, and firm characteristic controls for regional location of firm industry and the median log wage of the initial firm in 1978. Huber-White standard errors are shown from clustering by father ID. 
Table 8

Effects of Father's Income and Father Displacement on Child's Earnings, Unemployment and Assistance Receipt by Father's Income Quartile in 1978

\begin{tabular}{|c|c|c|c|c|}
\hline Income Quartile: & (1) & (2) & (3) & (4) \\
\hline Dependent var: & \multicolumn{4}{|c|}{ Log Earnings } \\
\hline Father's Log Income & $\begin{array}{c}0.381 \\
{[0.119]}\end{array}$ & $\begin{array}{c}0.405 \\
{[0.210]}\end{array}$ & $\begin{array}{c}0.359 \\
{[0.189]}\end{array}$ & $\begin{array}{c}0.298 \\
{[0.068]}\end{array}$ \\
\hline \multirow[t]{2}{*}{ Father Displaced } & $\begin{array}{c}-0.191 \\
{[0.088]}\end{array}$ & $\begin{array}{c}-0.111 \\
{[0.087]}\end{array}$ & $\begin{array}{c}0.085 \\
{[0.059]}\end{array}$ & $\begin{array}{c}-0.09 \\
{[0.070]}\end{array}$ \\
\hline & \multicolumn{4}{|c|}{ Receipt of UI } \\
\hline Father's Log Income & $\begin{array}{c}0.034 \\
{[0.015]}\end{array}$ & $\begin{array}{c}-0.030 \\
{[0.070]}\end{array}$ & $\begin{array}{l}-0.095 \\
{[0.066]}\end{array}$ & $\begin{array}{c}-0.170 \\
{[0.026]}\end{array}$ \\
\hline Father Displaced & $\begin{array}{c}0.067 \\
{[0.026]}\end{array}$ & $\begin{array}{c}0.026 \\
{[0.024]}\end{array}$ & $\begin{array}{c}-0.019 \\
{[0.022]}\end{array}$ & $\begin{array}{c}0.006 \\
{[0.024]}\end{array}$ \\
\hline & \multicolumn{4}{|c|}{ Receipt of Social Assistance } \\
\hline Father's Log Income & $\begin{array}{l}-0.017 \\
{[0.011]}\end{array}$ & $\begin{array}{l}-0.161 \\
{[0.046]}\end{array}$ & $\begin{array}{c}-0.158 \\
{[0.039]}\end{array}$ & $\begin{array}{c}-0.063 \\
{[0.013]}\end{array}$ \\
\hline Father Displaced & $\begin{array}{c}0.042 \\
{[0.018]}\end{array}$ & $\begin{array}{c}0.028 \\
{[0.015]}\end{array}$ & $\begin{array}{c}0.009 \\
{[0.016]}\end{array}$ & $\begin{array}{c}0.020 \\
{[0.017]}\end{array}$ \\
\hline
\end{tabular}

Notes: The sample of fathers are split by income quartile based on average income between 1978 and 1981. The table shows results from regressions run separately by father's income quartile. All regressions include fixed effects for birth cohort interacted with gender, and firm characteristic controls for regional location of firm industry and the median log wage of the initial firm in 1978. Huber-White standard errors are shown from clustering by father ID. 
Table 9

Effects of Father's Displacement in 1989

on Son's Earnings, Unemployment and Assistance Receipt

Father Displaced when Son Aged 19 to 21

\begin{tabular}{|c|c|c|c|}
\hline & $\begin{array}{c}\text { Log Son's Earnings } \\
\text { Earnings }\end{array}$ & $\begin{array}{c}\text { Receipt of } \\
\text { UI }\end{array}$ & $\begin{array}{c}\text { Receipt of } \\
\text { SA }\end{array}$ \\
\hline $\begin{array}{l}\text { Father's Residual } \\
\text { Log Income }\end{array}$ & $\begin{array}{c}0.342 \\
{[0.021]}\end{array}$ & $\begin{array}{c}-0.072 \\
{[0.006]}\end{array}$ & $\begin{array}{l}-0.039 \\
{[0.004]}\end{array}$ \\
\hline Father Displaced & $\begin{array}{c}0.008 \\
{[0.023]}\end{array}$ & $\begin{array}{l}-0.004 \\
{[0.007]}\end{array}$ & $\begin{array}{l}-0.001 \\
{[0.008]}\end{array}$ \\
\hline Number of Obs. & 39856 & 41197 & 41197 \\
\hline
\end{tabular}

Notes: All regressions include fixed effects for birth cohort interacted with gender, and firm characteristic controls for regional location of firm industry and the median log wage of the initial firm in 1978. Huber-White standard errors are shown from clustering by father ID. 
Table 10

Estimated Differences In Father's Characteristics Between Early Leavers and Displaced Workers

\begin{tabular}{|c|c|c|c|c|}
\hline & $\begin{array}{l}\text { Log Father's } \\
\text { Income }\end{array}$ & $\begin{array}{l}\text { Mother's } \\
\text { Earnings }\end{array}$ & $\begin{array}{c}\text { Father's } \\
\text { Age }\end{array}$ & Unmarried \\
\hline Left Early & $\begin{array}{l}0.019 \\
(0.02)\end{array}$ & $\begin{array}{l}-471.68 \\
(583.60)\end{array}$ & $\begin{array}{l}-0.404 \\
(0.27)\end{array}$ & $\begin{array}{l}-0.008 \\
(0.01)\end{array}$ \\
\hline Firm Fixed Effects? & Yes & Yes & Yes & Yes \\
\hline Number of Observations & 59,730 & 60,277 & 60,277 & 60,277 \\
\hline R-squared & 0.50 & 0.31 & 0.30 & 0.34 \\
\hline
\end{tabular}

Table 11

IV and Reduced From Results including Early Leavers

\begin{tabular}{lcccc}
\hline & $\begin{array}{c}\text { Child' Log } \\
\text { Income }\end{array}$ & Child on UI & $\begin{array}{c}\text { Child on } \\
\text { SA }\end{array}$ & \\
& & & & \\
Log Father's & 0.288 & -0.022 & -0.044 & \\
Income & $(0.016)$ & $(0.004)$ & $(0.002)$ & \\
Displaced in 1982 & -0.08 & 0.016 & 0.015 & \\
& $(0.034)$ & $(0.009)$ & $(0.006)$ & \\
& & & & \\
& & & Log Father's & -0.001 \\
First Stage: Dependent Variable: & & & Income & $(0.001)$ \\
& & & & 0.793 \\
& & & & $(0.008)$
\end{tabular}

